\title{
A Big Leap From Its Normal Distribution, Two Hahn's Short-Tailed Fruit Bats (Carollia subrufa) Reported in Far Southwestern Costa Rica.
}

David A Rodriguez ( $\sim$ david.rodriguez@fincacantaros.org )

Finca Cántaros Environmental Association

Wim de Backer

Monteverde BatJungle

Lilly Briggs

Finca Cántaros Environmental Association

\section{Research Article}

Keywords: Phyllostomidae, Carollia subrufa, distribution, San Vito, Costa Rica, Panama.

Posted Date: April 20th, 2021

DOI: https://doi.org/10.21203/rs.3.rs-369842/v1

License: (c) (i) This work is licensed under a Creative Commons Attribution 4.0 International License.

Read Full License 
A big leap from its normal distribution, two Hahn's short-tailed fruit bats (Carollia subrufa) reported in far southwestern Costa Rica.

David A. Rodríguez. ${ }^{1,2,3}$

Wim de Backer. ${ }^{2,3}$

Lilly Briggs. ${ }^{1}$

${ }^{1}$ Finca Cántaros Environmental Association.

${ }^{2}$ Monteverde Bat Jungle.

${ }^{3}$ Monteverde Conservation League.

Address of Correspondent: David A. Rodríguez, Wildlife Manager at Finca Cántaros Environmental Association, San Vito de Coto Brus, Costa Rica: david.rodriguez@,fincacantaros.org

\begin{abstract}
Populations of Hahn's short-tailed fruit bats (Carollia subrufa) are found from northwestern Mexico to the tropical dry forests of northeastern Costa Rica, with but two reports in the Monteverde area and another in Dominical. Here we report two captures registered 310 kilometres south of their normal range in the country; specifically, in San Vito de Coto Brus. Due to the location of San Vito a mere 10 kilometres from the Panamanian border, we suggest the possibility of a new mammal species for that country. Finally, we encourage continued efforts to better understand bat populations in this region of the isthmus.
\end{abstract}

Key words: Phyllostomidae, Carollia subrufa, distribution, San Vito, Costa Rica, Panama.

\title{
Background.
}

With more than 1400 species of identified bats in the world ${ }^{1}$, the order Chiroptera has the second highest species diversity among all terrestrial mammals on Earth, they are surpassed only by rodents ${ }^{2}$. The diversity of bats in Costa Rica is among the richest in the world, with 121 cataloged species ${ }^{3,4}$, distributed among nine families and 66 genera. This small country with only 
$0.03 \%$ of the entire terrestrial surface area of the planet holds more than $8 \%$ of all the bat species in the world 5 .

The radiation of the family Phyllostomidae to which Carollia genus is assigned has given rise to a wide range of species employing an equally wide range of feeding strategies ${ }^{6}$. The family includes insectivores, carnivores, frugivores, nectarivores, as well as sanguinivores (blood feeders) ${ }^{7}$. The Phyllostomidae is a family of approximately 160 species found exclusively in tropical and subtropical regions of the Western Hemisphere ${ }^{8}$. Short-tailed fruit bats are characterized by their extensive geographic distributions and local abundance; as such they are considered the most common mammals among neotropical fauna ${ }^{9}$. In Costa Rica, four of the eight short-tailed bat species have been documented $^{10,11}$.

The records of the Hahn's short-tailed fruit bat (Carollia subrufa) species to date have been largely limited to tropical dry forest on the Pacific slope, from Mexico to the northeast of Costa Rica and potentially to Panama, from sea level up to at least 1200 meters $^{10,12,13}$. An individual was captured and reported three kilometres northeast of Dominical $(9.279 \mathrm{~N},-83.862 \mathrm{~W})$ at 300 meters above sea level in $2007^{14}$. Until recently this was the southernmost record of the species documented. In conversation with Dr. Richard LaVal (January 2021) we found that an individual was caught in San Luis, Monteverde, at 1200 meters. More recently, in 2020, a non-reproductive adult female was caught by Wim de Backer and Eduardo Artavia in Monteverde, at 1350 meters.

The Finca Cántaros Environmental Association (FCEA) recently initiated a study in collaboration with the Monteverde Bat Jungle (MBJ), led by bat biologist Wim de Backer, with the goal of understanding the bat populations on the property. The property includes secondary growth forest, a lake, and pasture that is undergoing active and passive reforestation.

This report documents the capture of two individuals of $C$. subrufa at Finca Cántaros in San Vito de Coto Brus, located in a life zone identified as Premontane Wet Forest ${ }^{15}$ at an elevation of 1190 meters. 


\section{Materials and methods.}

Since July 2020, the MBJ team has made three visits to Finca Cántaros. During each visit six mist-nets are set up (3 hours of efforts/39 meters of mist-nets), with each net using aluminum poles three meters in height. Bat experts, Finca Cántaros staff, and local volunteers are involved in the mist-netting and handling of the bats, each wearing masks and gloves. Wim de Backer, the lead bat researcher, has the necessary permission and certification from the Costa Rican Ministry of the Environment and Energy-National Park System (MINAE and SINAC are the acronyms in Spanish) to manipulate wildlife known as a Scientific Passport (number 046-2020-ACAT). To conduct the research, the team followed all protocols, guidelines and regulations established by the American Society of Mammalogists ${ }^{16}$. Nets were opened at 5:20 p.m. and closed at 9:30 p.m.

\section{Results.}

On October 31, 2020, we captured the first individual, while the second individual was captured on January 30, 2021. The first one was captured in one of the nets at the edge of the property's secondary forest (approximately 25 years old), where it meets the open area undergoing active reforestation since 2019. The second capture took place again in one of the nets located in the secondary forest, around 70 meters from the first capture

The specimens were identified using York et al.'s (2019) key. The measurements of the female were: forearm $\pm 37.05 \mathrm{~mm}$, tibia $17 \mathrm{~mm}$, calcar $0.53 \mathrm{~mm}$, tail $10 \mathrm{~mm}$, and ear $10 \mathrm{~mm}$. The male measurements were: $\pm 39.00 \mathrm{~mm}$, tibia $17.60 \mathrm{~mm}$, calcar $0.70 \mathrm{~mm}$, tail $9.10 \mathrm{~mm}$, and ear $9.90 \mathrm{~mm}$.

In both sexes the forearms and the feet had little noticeable fur; the chin of the snout slightly squared; the tail extends to the midpoint of the uropatagium, and extends ventrally a short distance from the tail membrane; the nasal leaf slightly longer than wide; the ears and nasal leaf well developed, but not exceptionally long; the central wrinkle larger and distinctively surrounded by small 
protuberances; both individuals presented inferior bilobed incisors; the fur did not appear to have bands, and was grayish-brown and short. (Photos 1and 2). All these characters agree with Pine ${ }^{17}$.
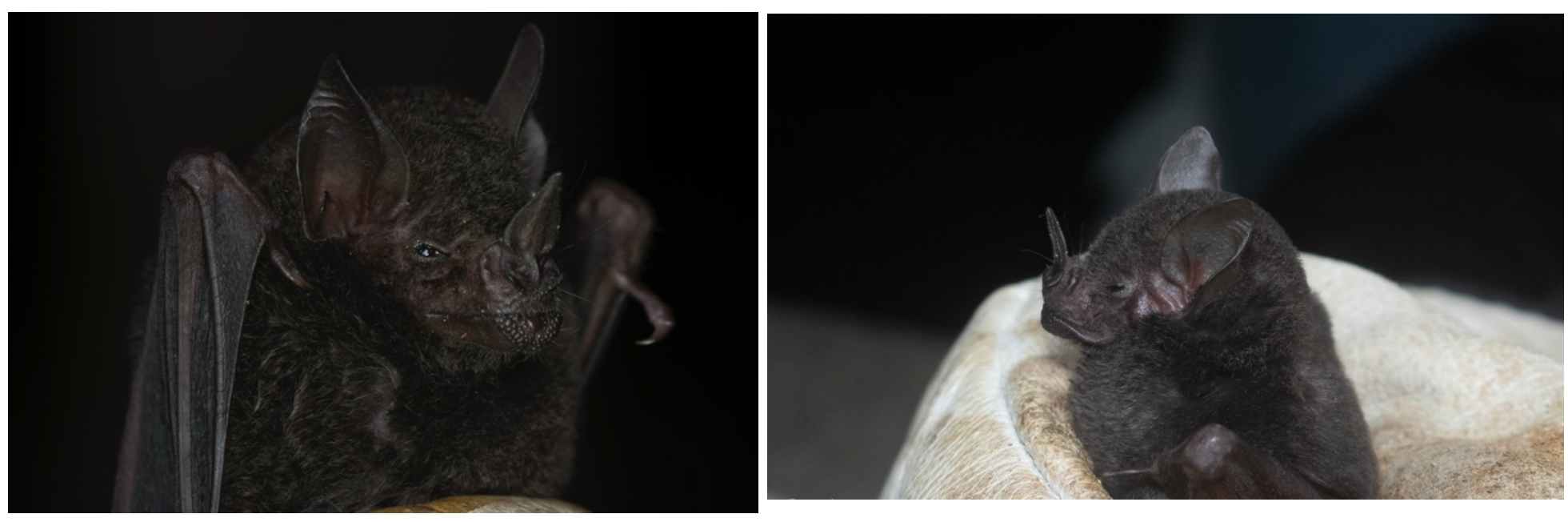

Photos 1 and 2. Left: First individual (female) captured on October 31, 2020. Right: Second individual (male) captured on January 30, 2021.

\section{Discussion.}

Encounters with species in areas where they were previously unreported are becoming increasingly common. A variety of factors can account for this phenomenon: more researchers in the field, land use change, and climate change $^{18,19}$. The sites where C. subrufa was captured include the plants on whose fruits this species typically feeds ${ }^{1,20,21}$, suggesting that Finca Cántaros offers an adequate food supply for this species, due to the abundance of Piper and Solanum species around the property. 


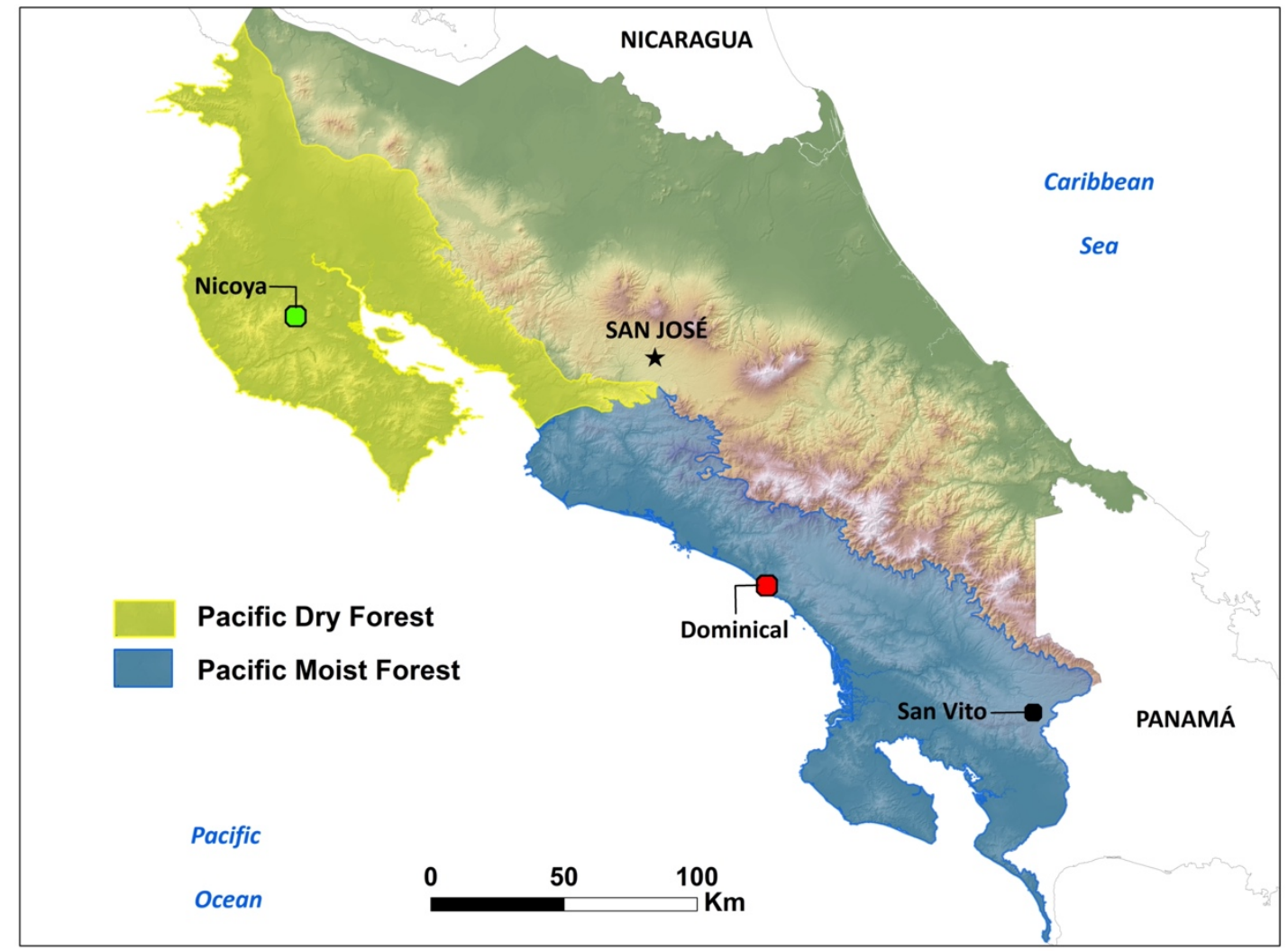

Map 1. The light-green square marks the area where the species is commonly found; the red square denotes the site where the individual was captured in 2007; the black square indicates the location of Finca Cántaros.

The distance between where C. subrufa was captured in 2007 in Dominical, with respect to its known distribution in Guanacaste, is approximately 200 kilometres. The distance between Dominical and Finca Cántaros, in San Vito, is approximately $110 \mathrm{~km}$. Between Nicoya and San Vito are approximately 310 $\mathrm{km}$. As such, the capture of C. subrufa a mere $10 \mathrm{~km}$ from the Panamanian border allows us to hypothesize that this species could have an even more extensive range, is not only restricted to the dry forest habitat ${ }^{22}$, but also occurs in wet forest and Premontane Moist Forest (Map, 1). This suggests that future studies should include collaboration with our neighboring country. 


\section{Acknowledgements.}

We would like to thank Finca Cántaros Environmental Association for allowing us to study bat populations on their property. Thank you to Dr. Richard LaVal for his valuable comments and suggestions on the manuscript. Thanks to Henry Sandí and Randall Jiménez for their help in the field and for the photos of Hahn's short-tailed fruit bat (C. subrufa) that they provided. Finally, thank you to Randy Chinchilla of the Monteverde Institute for creating the map.

\section{References.}

${ }^{1}$ Zachos, F. E. (2020). DE Wilson and RA Mittermeier (chief editors): Handbook of the Mammals of the World. Vol. 9. Bats.

${ }^{2}$ Heard, D. J. (2003). Chiroptera (bats). Zoo and Wild Animal Medicine. 5th edn. Eds ME Fowler, RE Miller. WB Saunders Co, 315-333.

${ }^{3}$ York, H. A., Rodríguez-Herrera, B., Laval, R. K., Timm, R. M., \& Lindsay, K. E. (2019). Field key to the bats of Costa Rica and Nicaragua. Journal of Mammalogy, 100(6), 1726-1749.

${ }^{4}$ Carrion-Bonilla, C. A., \& Cook, J. A. (2020). A new bat species of the genus Myotis with comments on the phylogenetic placement of M. keaysi and M. pilosatibialis. Therya, 11(3), 508.

${ }^{5}$ Wainwright, Mark. (2002). The Natural History of Costa Rican Mammals. Zona Tropical Publications.

${ }^{6}$ Fleming, T. H., Dávalos, L. M., \& Mello, M. A. (Eds.). (2020). Phyllostomid Bats: A Unique Mammalian Radiation. University of Chicago Press.

${ }^{7}$ Villalobos, F., \& Arita, H. T. (2010). The diversity field of New World leafnosed bats (Phyllostomidae). Global Ecology and Biogeography, 19(2), 200211. 
${ }^{8}$ Simmons, N. B. (2005). Order chiroptera. Mammal species of the world: a taxonomic and geographic reference, 1, 312-529.

${ }^{9}$ Murillo-García, O. E. (2014). Murciélagos de cola corta (Carollia:

Phyllostomidae) del Parque Nacional Natural Gorgona (Colombia) y sus implicaciones biogeográficas. Revista de Biología Tropical, 62, 435-445.

${ }^{10}$ LaVal, R. K., \& Rodríguez-H, B. (2002). Murciélagos de Costa Rica Instituto Nacional de Biodiversidad. Costa Rica. pp.

${ }^{11}$ Gardner, A. L. (Ed.). (2008). Mammals of South America, volume 1: marsupials, xenarthrans, shrews, and bats (Vol. 2). University of Chicago Press.

${ }^{12}$ Eisenberg, J. F. (1989). Mammals of the Neotropics: The northern Neotropics. University of Chicago Press, Chicago, Illinois.

${ }^{13}$ Reid, F. (1997). A field guide to the mammals of Central America and Southeast México: Oxford University Press. New York, 334.

${ }^{14}$ Christenson, K., \& McFarlane, D. (2007). An ecologically-significant range extension for Hahn's short-tailed fruit bat (Carollia subrufa) in Southwestern Costa Rica. Chiropt. Neotrop, 13, 319-321

${ }^{15}$ Holdridge, L. R. (1967). Life zone ecology Centro Científico Tropical. San José, Costa Rica, 206.

${ }^{16}$ Sikes, R. S., \& Animal Care and Use Committee of the American Society of Mammalogists. (2016). 2016 Guidelines of the American Society of Mammalogists for the use of wild mammals in research and education. Journal of mammalogy, 97(3), 663-688.

${ }^{17}$ Pine, R. H. (1972). The bats of the genus Carollia (Vol. 8). Texas A \& M University, Texas Agricultural Experiment Station.

${ }^{18} \mathrm{LaVal}, \mathrm{R} . \mathrm{K}$. (2004). Impact of global warming and locally changing climate on tropical cloud forest bats. Journal of Mammalogy, 85(2), 237-244.

${ }^{19}$ Pounds, J. A., Fogden, M. P. L., \& Masters, K. L. (2005). Responses of natural communities to climate change in a highland tropical forest. Case study. See Lovejoy \& Hannah, 2005, 70-74. 
${ }^{20}$ Fleming, T. H. (1988). The short-tailed fruit bat: a study in plant-animal interactions. University of Chicago Press.

${ }^{21}$ Lobova, T. A., Geiselman, C. K., \& Mori, S. A. (2009). Seed dispersal by bats in the Neotropics. New York Botanical Garden.

${ }^{22}$ Medina-Fitoria, A., Williams-Guillen, K., Chambers, C., Chávez-Velásquez, M., \& Martinez-Fonseca, J. G. (2020). DIVERSIDAD DE MURCIÉLAGOS Y USO DE HÁBITAT EN EL PARQUE NACIONAL VOLCÁN MASAYA, EN EL PACÍFICO DE NICARAGUA. Revista Mexicana de Mastozoología (Nueva Época), 10(1), 1-20. 


\section{Figures}
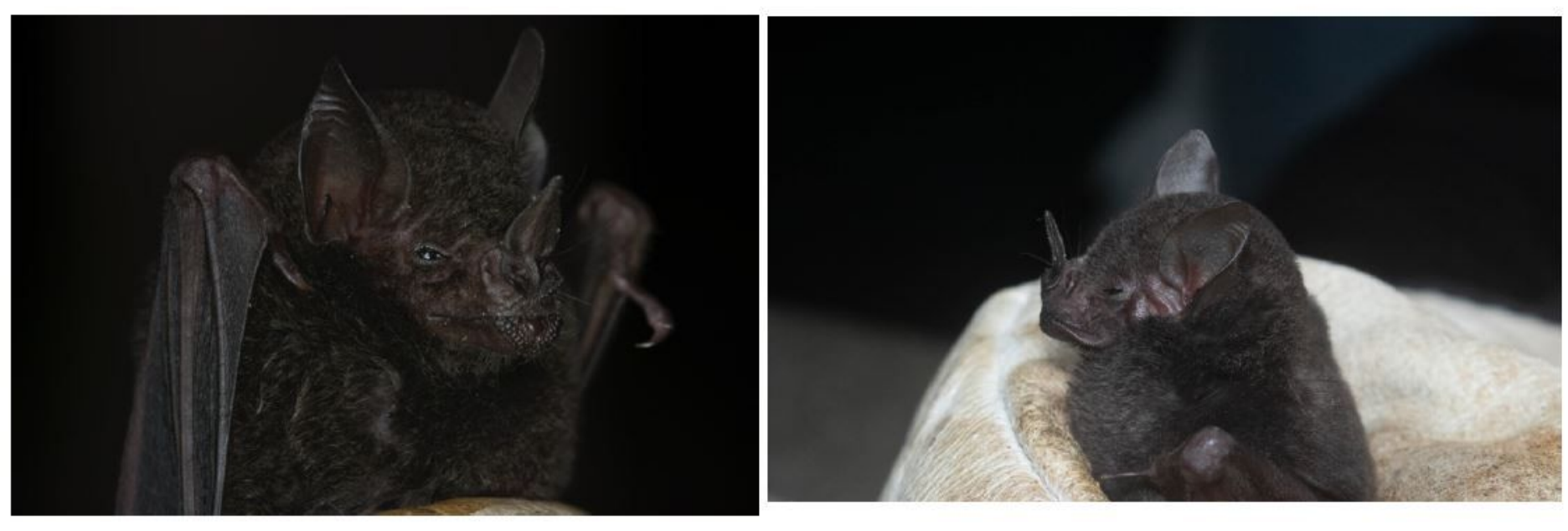

Figure 1

Left: First individual (female) captured on October 31, 2020. Right: Second individual (male) captured on January 30, 2021. 


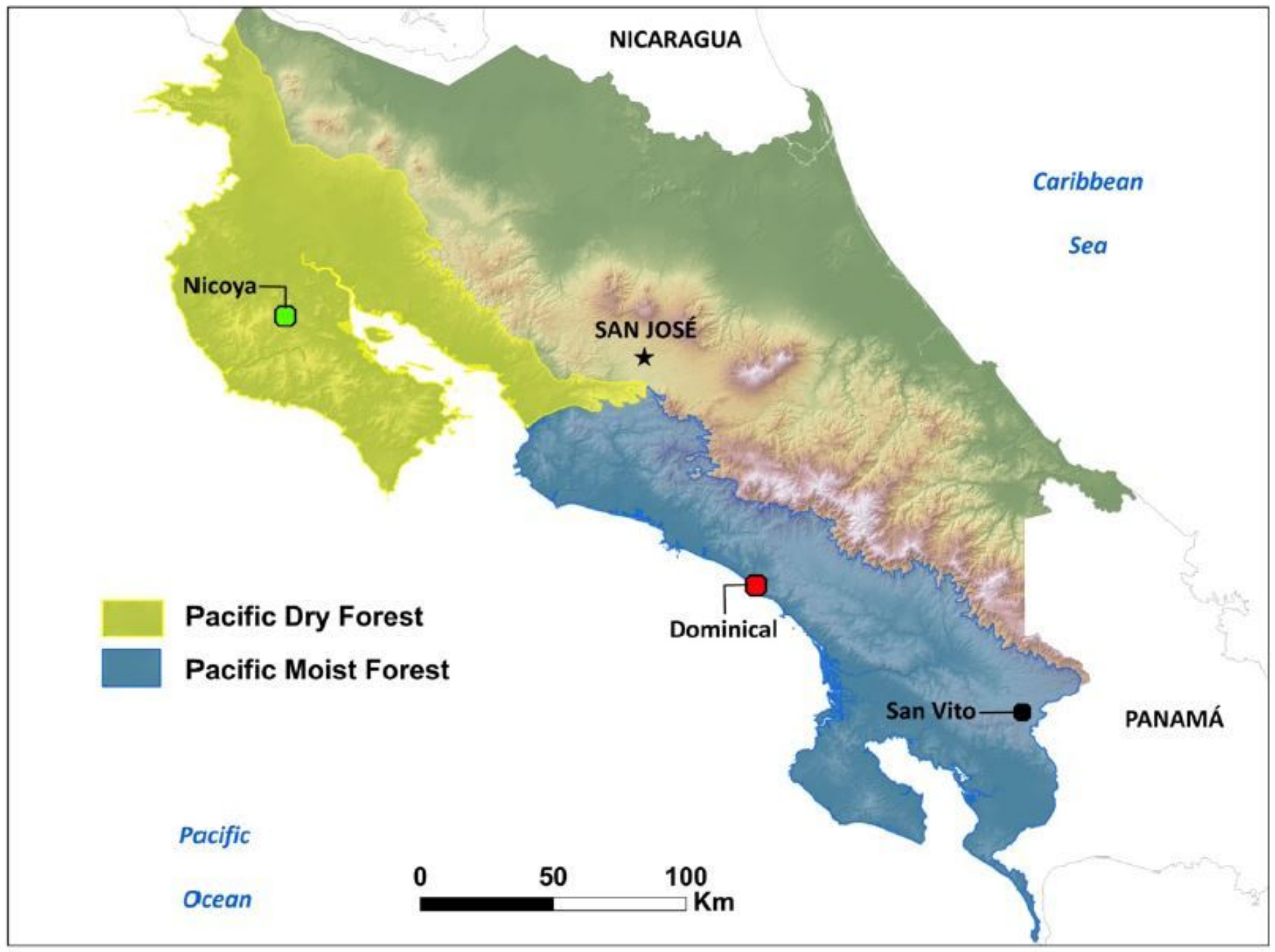

\section{Figure 2}

The light-green square marks the area where the species is commonly found; the red square denotes the site where the individual was captured in 2007; the black square indicates the location of Finca Cántaros. Note: The designations employed and the presentation of the material on this map do not imply the expression of any opinion whatsoever on the part of Research Square concerning the legal status of any country, territory, city or area or of its authorities, or concerning the delimitation of its frontiers or boundaries. This map has been provided by the authors 